\title{
Teaching Aqidah: Islamic Studies in Malaysia
}

\author{
Wan Hassan Wan Embong*, Ajmain Jimaain Safar, Bushrah Basiron \\ Islamic Civilization Academy, Faculty of Social Sciences and Humanities, Universiti Teknologi Malaysia, UTM Johor \\ Babru, Johor, Malaysia \\ *Corresponding author: abawidad@utm.my
}

\author{
Article history \\ Received: 2019-06-24 Received in revised form: 2019-11-02 Accepted: 2019-11-04 Published online: 2020-02-29
}

\begin{abstract}
It is widely agreed that Malaysia will achieve sustainable prosperity when its citizen live together in harmony. Moreover, a good society derives from good families and good families derive from righteous individuals who transmit insight that builds good character. In Islam, the transmission of this insight is called aqidah (belief system), which continually plays an active role in the enhancement of personal accountability. This study took a qualitative approach using personal interviews to determine methods used to teach aqidab in Malaysia. Findings revealed four methods including multimedia, slide presentations, group discussions and teacher didactics.
\end{abstract}

Keywords: aqidah (belief), individual personality, social responsibility, teaching method 


\subsection{INTRODUCTION}

Effective teaching and learning depends on a teacher's ability to create an interactive environment (Azmi \& Halim, 2007). An innovative teacher has skills and knowledge that show the relevance of subject matter to daily living and potential spiritual enhancement that can be integrated with contemporary issues aligned with nation building (Huda \& Sabani, 2018). Thus, the enhancement of individual personality via education can begin early on. Since Islamic values play an important role in shaping human personality with divine input, the process can be integrated with innovative approaches where students and teachers have access to certain technologies (Huda \& Kartanegara, 2015). It is crucial to incorporate a complex subject like aqidah because effective teaching extends beyond the cognitive to the affective domain.

Any educational initiative that nurtures moral values also enhances aqidah when beliefs align with Islamic objectives and directly relate to the core concept of Shahada. In particular, to voice Islamic values is a major contribution to their transmission in the course of human development, particularly among Muslims (Huda et al., 2016a) where implementation grants tranquility and happiness. Al-Qaradawi (1990) says happiness is like a tree that grows within the soul and that faith in Allah SWT and the Hereafter are resources that nurture this tree. Accordingly, feelings of contentment and happiness attend iman (belief). He also asserted there was no strength that matched that of the religious force to ensure submission to law and social unity. Hence, aqidab is considered the righteous path to all knowledge and understanding because it conveys core Islamic values that crystalize Muslim identity. This begins by instilling correct qualities and attitudes in students, a process that is difficult but crucial. Other efforts to bring individual peace are unnecessary beyond this framework.

Outstanding approaches to the establishment of Islamic moral and ethics include communal service (Huda et al., 2017), awareness of corporate social responsibility (Huda et al. 2018a), and the transmission of leadership (Huda et al., 2018b). Many studies have been done but there is a lack of scholarly attention given to the strategic elaboration of the Islamic system of belief. Hence, this article examines the potential value of a belief system that enhances personal qualities and Muslim society beginning with education in basic aqidah, the history of Islamic education in Malaysia, aqidah and the philosophy of state education, aqidab in Islamic studies, teaching aqidah, and the experience of teaching aqidab in Malaysian secondary schools.

\subsection{BASIC EDUCATION IN THE ISLAMIC FAITH}

Aqidah education, according to Ramli Awang (2012), comprises the fundamental principles of submission and obedience to Allah SWT alone as Almighty God. The essence of the phrase ' $L a$ ilah illa Allab' is to submit one's entire being to Allah. During the first thirteen years of Islam in Mecca, the growth of iman in each individual had greater emphasis than did specific acts of worship. This included eliminating the idea of 'gods' other than Allah SWT, along with the enjoining of ulubiyyah (worship) and the concept of 'ubudiyyah and their relationship. Drawing close to Allah SWT (At-Taqarrub Ila Allab) is the meaning behind the phrase محمد رسول اله Dfter believing that Allah SWT is the only God, what follows is acknowledging the Holy Prophet as the ideal example to be followed in submission to Allah. Thus, every word and action of the Prophet should be followed in the course of daily living. Mohammad's faith towards Allah is therefore not just another biographical account but rather a special model. Consequently, the study, understanding and practice of the Prophet's words and actions in daily life are of paramount importance (al-Qattan, 1986; al-Sibagh, 1990).

Page | 26 
Generally, discussions and debates related to aqidab are subjective and concern supernatural matters of the unseen. The present orientation enhancing our understanding (Huda et al., 2016b) of educational outcomes and objectives, which are difficult to measure and assess. Teaching aqidah is deemed successful when students demonstrate complete trust in Allah and also implement concepts leading to good deeds on a daily basis. As such, the final learning outcome is not an 'A+' on an exam but rather evidence of submission to Allah SWT and the Hereafter. This is what Syed Qutb (1978) indicated as 'successful education in Aqidab' as shown by the Prophet's companions:

Rasulullah s.a.w. succeeded in guiding his companions (sahabah) to strong faith. Each one translated their firm faith by practicing it when eating and when walking in the market until they were said to be walking Qur'ans, living on the surface of the earth. Every individual was representative of Islam and its beauty. This ideal character can be seen in every Muslim.

\subsection{HISTORY OF ISLAMIC EDUCATION IN MALAYSIA}

Islamic education in Malaysia began with the arrival of Islam in Melaka around the 14th Century CE (Mohd Roslan \& Wan Mohd Tarmizi, 2011). Muslim students soon went to the Middle East as the center of Islamic knowledge; initially to Mecca then to al-Azhar University. Sheikh Abdul Malik Abdullah (1650-1736) of Terengganu was the first Malaysian to study in Mecca (Othman, 1998). Malaya Islamic studies then spread from gatherings in an imam's house to the institution of the Pesantren, a system originating with traditional Javanese pondoks: dormitories where students learned religious philosophies; and to the Madrasah, religious school or colleges for the study of Islam. This system evolved further under British colonialism (Salleh, 1997) with two streams: the Pesantren system, offering Islamic education, and the National system. Having two curricular streams in the madrasah system caused stagnation due to a lack resources, and eventually led to government intervention to modify the curriculum (Salleh, 1997).

Islamic education ran independently during the colonial period until the Razak Statement of 1956, which was then followed by Rahman Talib's Statement in 1960. The latter placed all education under the National Education System (NES) and the Education Act of 1961 incorporated Islamic studies within the school schedule. On this, Ahmad Mohd Salleh wrote:

The Malaysian Constitution makes it clear that Islam is the official federal religion with full rights of practice (Items 3:1 and 12:3). The Razak Statement (1956) and the Rahman Talib Statement (1960) state that if there are 15 Muslim students, then Islamic Studies must be taught by qualified teachers. The Education Act of 1996, Section 50:1, states that if in an educational institution has 5 or more Muslim students, Islamic Studies must be taught in said institution. The National Curriculum Education Regulation (1997), item 3:4 of Schedules 13 and 14, provide for a minimum of one week for the teaching of Islamic Studies as follows: a) Primary school, 6 times; b) Lower secondary school, 4 times [3+ 1 (Practical) +2 (Addition)]; c) Upper secondary school, 4 times [3 +1 (Practical)].

Professor Abdul Halim (1989) believes that the formalization of Islamic studies began with the Education Act of 1961, a direct result of Rahman Talib's Report. It continues to require every Muslim student's participation in Islamic Religious Knowledge and tests as directed by the Cabinet Committee led by then Deputy PM, Dato 'Seri Dr. Mahathir Mohamed. KBSM Islamic Studies thereafter became part of the complete KBSM curricula for all National Secondary Schools within the NES. It is compulsory and must be taken by all Islamic pupils. Curricula is the responsibility of the Department of Islamic and Moral Education (JAPIM), (Mustafa, 2007), as directed by the 
Ministry of Education. Akidab is a core subject in KBSM Islamic studies in high schools. KBSM was replaced by KSSM in 2012.

\subsection{AQIDAHAND THE PHILOSOPHY OF STATE EDUCATION}

The National Education Philosophy (NEP) was introduced in 1987. In essence, NEP concerns the social engineering of human capital in the education sector. According to Mohd Shafiee bin Hamzah et al. (2015), Malaysia introduced an educational philosophy that clearly states goals and direction for national education. By drafting its own NEP, Malaysia crafted a unique design for excellence by not following norms adopted by other countries. The National Education Philosophy reads as follows:

Education in Malaysia is a continuous effort towards further developing the potential of the individual in a comprehensive and integrated way to produce balanced and harmonious people in terms of intellectual, spiritual, emotional, and physical harmony based on belief-in and obedience-to God. This effort is aimed at producing Malaysian citizens who are knowledgeable, skilled, noble, responsible, and capable of achieving personal well-being and then contributing to the harmony and prosperity of families, communities and countries (Ministry of Education, 2017, 16).

This philosophy implies an integrated approach that emphasizes developing human potential in a comprehensive and balanced manner that educates mind and heart so that students recognize the existence of God while subjecting themselves to His service (Nur Hafizoh and Rohana, 2013). This philosophy assures elements of faith based on 'trust and obedience to God', as written in the NEP text, and clearly demonstrates that faith is the foundation Malaysia's educational activities. Tajul Arifin (2005) says the phrase is intended to instill confidence that men, material and natural resources do not occur on their own because God creates everything. This belief is firmly instilled to affect adherence to divine intention in every human activity.

When trusting that humans and the world were created, and that laws of nature are the laws of God, humans must therefore obey God to actualize this trust by being responsible to Him in their administrative efforts to achieve well-being now and Hereafter. Both concepts can be used to purify Western scientific methods and ideas that cause doubt and negatively affects believing students regarding revelation and divine existence. Thus, a unified educational system founded on faith in revealed knowledge furthers the goal of establishing trust in God (Arifin, 2005, 8)

Naturally, faith therefore becomes elemental to all learning activities in Malaysian schools. Hence, this same spirit is applied across curricula and serves as a compass indicating the righthand of puppetry that then infuses student identity. Nik Aziz Nik Pa (2008) argued that the purpose of the NEP is to produce human capital using God oriented narratives. From the educationist's point of view, per Mohd Shafiee Hamzah et al. (2015), NEP Philosophy emphasizes education as an ongoing effort that is God-centered rather than human-centered. The process of developing human potential, therefore, does not solely focus on physical and intellectual aspects but involves spiritual, intellectual, emotional and social aspects in a comprehensively integrated format based on belief-in and obedience-to God, versus a materialist secular approach founded on debunked evolution:

The theory of evolution is not properly scientific and is simply inadequate at explaining the origin of life. Darwinism was an interesting idea in the 19th century, when handwaving explanations gave a plausible, if not properly scientific, 
framework into which we could fit biological facts. However, what we have learned since the days of Darwin throws doubt on natural selection's ability to create complex biological systems - and we still have little more than handwaving as an argument in its favor.

$\sim$ Professor Colin Reeves, Dept of Mathematical Sciences, Coventry University

In other words, the NEP promotes a universal lifelong integrated process of education that creates real ties between spirituality and psycho-neurophysiological development in an effort to comprehensively enhance human potential (Nik Aziz Nik Pa, 2008, 27).

A theocentric cosmology and sociology is not at all awkward because it aligns with the Holy Qur'an, which makes religion the basis of faith per the doctrine of tawhid as manhaj or 'the way of human life'. Thus, the NEP is seen as unique because it is founded on divine revelation. Tajul Arifin (2002a) argued this is contrary to western thinkers such as Marx (socio-economic), or Sartre (existentialism and freedom), or Skinner (behavior), each of whom clearly rejected God and taught that human nature is determined by the individual through experience and interactions with external factors. Tajul Arifin (2002b) also saw the NEP formula as consistent with trust in God as a sound basis for optimally engineering human capital's potential.

\subsection{AQIDAHSTUDIES}

Wan Hassan (2014) depicted the NEP as a facilitator of Islamic Education Philosophy (IEP), specifically aqidah. Although the NEP is not fully in line with IEP in areas such as resources and educational objectives, its philosophical spirit approaches Islamic objectives and goals of aqidah as part of the Islamic curriculum for secondary schools, which also incorporates Ibadah, Figh, Seerah, Tafsirul Qur'an and Islamic History. If aqidab is crucial to the building of good character, in Islamic studies it constitutes a pillar for all subjects taught in school (Nordin et al., 2002). Hence, aqidab is vital because through it, all Islamic knowledge and virtues are realized. In addition, preaching aqidah is why all messengers were sent (Syahatah et al., 1998), which is also why all good deeds will not be accepted by Allah SWT unless the aqidah of the doer is on the right path. (Alavi, 2008). Alavi claims that Islamic studies eventually realize the same end goal when including aqidab:

However, in light of other literal etymons of the word education, especially in Islam, its definition is best defined by humans choosing God as their only and One Lord, to know and recognize Him, to love Him, to be freed from the shackles of all that is contrary to God, to act exactly according to His commandments and order, and to surrender and submit to Him.

Al-Qur'an places aqidah as its main focus for teaching and learning. Other aspects are more easily implemented when studies in aqidah are successful (Al-Qaradawi, 1990). This concept is explained by Allah SWT in the Qur'an. The following verse is a dialogue between Luqman and his son when explaining the concept of Islamic studies.

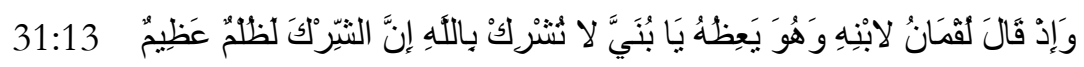

My son, do not attribute any partners to God: attributing partners to Him is a terrible wrong

When advising his son, Luqman began with aqidah, submission to Allah SWT. Only later does Luqman teach his son prayers and ethics. The syllabus, as arranged in the Qur'an, is direct guidance from Allah SWT, the All Knowing, the Most Wise. Islamic education must begin with childhood. 
Understanding the creed begins with self-application under proper guidance and discipline. One who lives on margins is in ignorance and tends to return to their original religion. Therefore, every Muslim must have a deep knowledge of privileges offered by the Islamic faith within the Muslim community. Aqidab is not easily formed because a stable heart requires understanding the false arguments that instill doubt. Thus, all positions need to be understood and logically and calmly accepted. (Ahmad Yunus et al., :2017)

\subsection{EXPERIENCE IN TEACHING $A Q I D A H I N$ SECONDARY SCHOOL}

Current teaching methods for studies in aqidah studies account for all factors that ensure effective learning while maintaining student interests, which change over time. We interviewed and studied the methodology of four experienced teachers in Islamic studies teachers from schools in Johor Bahru. Records were transcribed and themed using NVivo software. Our analysis identified four methods: multimedia presentations, slide presentations, discussions, and lectures. Other methods include storytelling, exercises, taking notes, substantiating existing knowledge, reflections on life, and ' $\mathrm{Q}$ and $\mathrm{A}$ ' sessions. This is summarised in Figure 1 which we name it as frequently used methods and normal used methods.

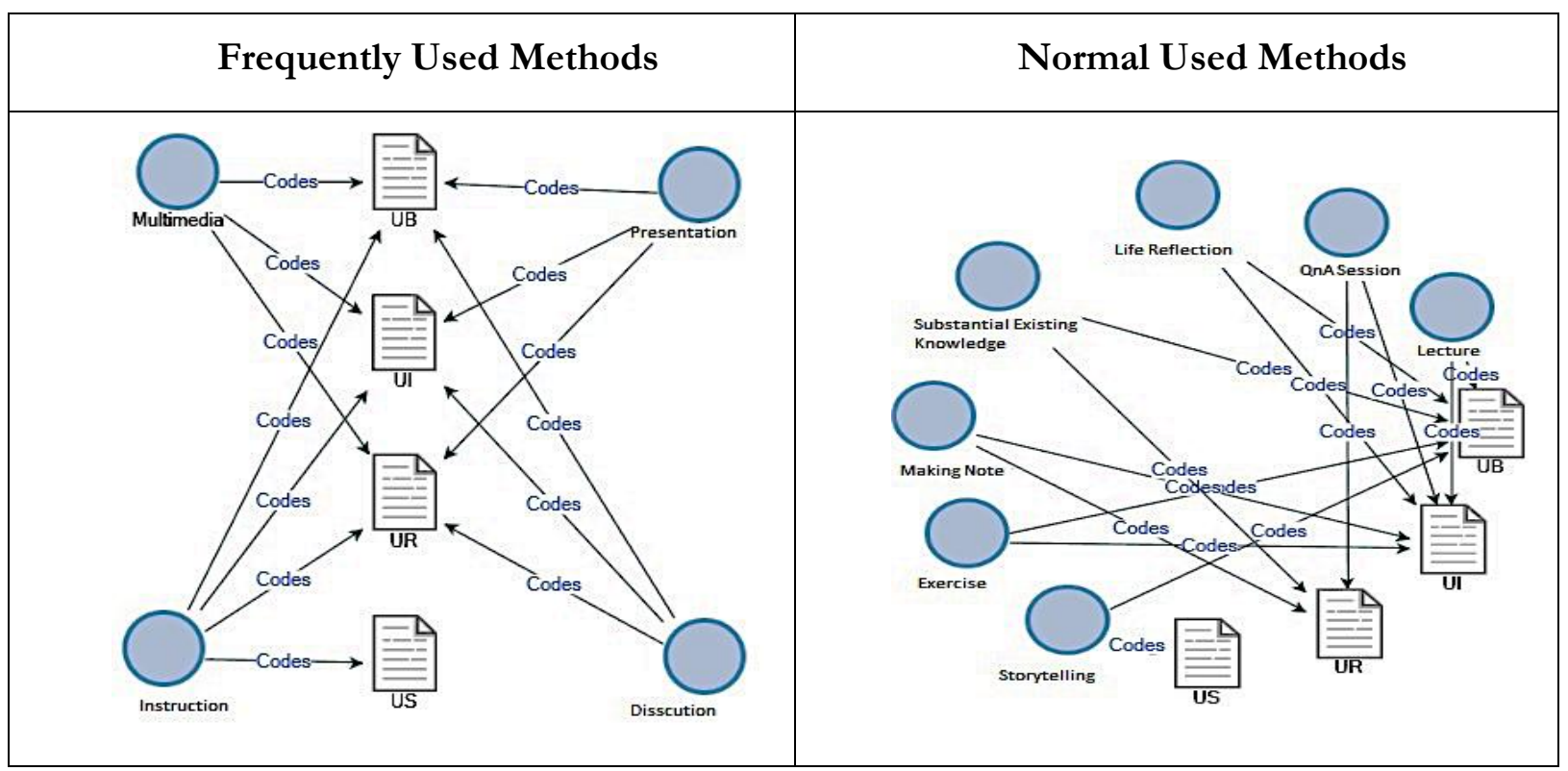

Figure 1: Graphs shown methods in frequently and normal used

Multimedia presentations were the most effective method identified. Respondents also used power point and ithink to aid their approach to teaching materials and were satisfied with learning outcomes. The use of IT is exceptionally helpful in aqidab studies. Similar to other subjects, IT innovation helps make a difficult subject matter more palatable. Wan Hassan (2014) reported that a video montage, whether in the form of acting, documentary or animation, has a significant impact on the learning process for aqidah studies.

Discussions allow students to divide into small groups for intellectual exchanges on topics provided by the teacher. The teacher ensures that each student is given time to think and contribute by conveying their ideas. Ideas are then presented to the class for general assessment and further discussions by everyone. This method commonly focuses on current issues. 
Lectures are the most popular method used by teachers. They are easier to prepare and require less time. Frequently, lecturers use Q \& A sessions to initiate discussions and assess levels of student comprehension to ensure effective material delivery. This method is generally reserved for topics that rely on facts and which require explanation rather than thinking skills. An example is the journey of rub (spirit) from lub mahfuz to mahshar.

\subsection{CONCLUSION}

Aqidab studies are crucial to Islamic studies and the national education system as a whole. The importance of this subject is informed by educators and the historical experience of Islamic studies from earlier generations. It is thus a core subject of formal Islamic education in Malaysia. As stated, the use of current technology increases teaching effectiveness so that all efforts are being made to shape a useful generation for the betterment of the nation.

\section{List of Reference}

Abdul Halim Mat Diah. (1989). Pendidikan Islam di Malaysia, Sejarah dan Pemikiran, Kuala Lumpur: ABIM.

Ahmad Mohd. Salleh. (1997). Pendidikan Islam: Falsafah, Pedagogi dan Metodologi. Shah Alam: Penerbit Fajar Bakti.

Ahmad Yunus Kasim, Samsuddin Abdul Hamid \& Misnan Jemali, (2017), Teaching of Islamic Faith (Akidah) among New Converted Muslim in Islamic Propagation Institute (PERKIM), Jumal Perspektif: Special Issue 1 (2017), (89-100).

Al Qur'an al Karim. (2005). Madinah: King Fahd Complex for the Printing of the Holy Qur'an.

Al-Qaradawi, Yusuf. (1990). al-Iman wa al-Hayah, Kaherah: Maktabah Wahbah.

Al-Sibagh, Muhammad Lutfi. (1990). Lambat fi 'Ulum al-Quran wa Ittijahat al-Tafsir, Beirut: Maktab al-Islami.

Dangiran Haji Mustafa. (2007). Pelaksanaan Pendidikan Islam ke Arah Pembentukan Masyarakat Hadhari dlm Nik Azis Nik Pa (ed), Pendidikan Islam dan Pendidikan Babasa Arab, Putrajaya: Yayasan Islam Hadhari.

Hamid Reza Alavi. (2008). "Nearness to God a Perspective on Islamic Education,” Religious Education Journal The Religious Education Association, 103(1), 5-21

Huda, M., \& Kartanegara, M. (2015). Islamic Spiritual Character Values of al-Zarnüjì’s Ta 'lìm al-Muta'allim. Mediterranean Journal of Social Sciences, 6(4), 229.

Huda, M., \& Sabani, N. (2018). Empowering Muslim children's spirituality in Malay Archipelago: integration between National Philosophical Foundations and Tawakkul (trust in God). International Journal of Children's Spirituality, 23(1), 81-94.

Huda, M., Jasmi, K. A., Alas, Y., Qodriah, S. L., Dacholfany, M. I., \& Jamsari, E. A. (2018a). Empowering Civic Responsibility: Insights From Service Learning. In Engaged Scholarship and Civic Responsibility in Higher Education, 144-165. IGI Global.

Huda, M., Jasmi, K. A., Mohamed, A. K., Wan Embong, W. H., \& Safar, J. (2016a). Philosophical Investigation of al-Zarnūjì's Ta'līm al-Muta'allim: Strengthening Ethical Engagement into Teaching and Learning. The social science, 11(22), 5516-5519.

Huda, M., Jasmi, K. A., Mustari, I., Basiron, B., \& Sabani, N. (2017). Traditional Wisdom on Sustainable Learning: An Insightful View From Al-Zarnuji's Ta 'lim al-Muta 'allim. SAGE Open, 7(1), 1-13.

Huda, M., Mat Teh, K. S., Nor Muhamad, N. H., \& Mohd Nasir, B. (2018b). Transmitting leadership based civic responsibility: insights from service learning. International Journal of Ethics and Systems, 34(1), 20-31.

Page | 31 
Huda, M., Mulyadi, D., Hananto, A. L., Nor Muhamad, N. H., Mat Teh, K. S., \& Don, A. G. (2018). Empowering corporate social responsibility (CSR): insights from service learning. Social Responsibility Journal, 14(4), 875-894.

Huda, M., Yusuf, J. B., Azmi Jasmi, K., \& Nasir Zakaria, G. (2016b). al-Zarnùjì’s Concept Of Knowledge (iilm). SAGE Open, 6(3), 1-8.

Kamarul Azmi Jasmi, \& Ab. Halim Tamuri (2007). Pendidikan Islam: Kaedah Pengajaran dan Pembelajaran, Johor: Universiti Teknologi Malaysia.

Manna’ al-Qattan (1986), Mababith fi 'Ulum al-Quran, Syria: Muassasah al-Risalah.

Ministry of Education (Edisi 4, 2017). Dasar Pendidikan Kebangsaan, Selangor: Firdaus Press Sdn. Bhd.

Mohd Roslan Mohd Nor, \& Wan Mohd Tarmizi Wan Othman (2011), "Sejarah dan Perkembangan Pendidikan Islam di Malaysia", al-Ta'dib: Jurnal Kependidikan Islam, Indonesia: Fakultas Tarbiyah, Institut Studi Islam Darussalam Pondok Modern Darussalam Gontor, 6(1):59-78.

Mohd Shafiee bin Hamzah, Azli Fairuz bin Laki, Rahimah binti Embong, Nik Murshidah Nik Din. (2015). Penerapan Akidah Dalam Dasar Pendidikan Malaysia: Analisis Terhadap Falsafah Pendidikan Negara Dan Islam Hadhari. Jurnal Islam dan Masyarakat Kontemporari Bil. 9 Januari 2015.

Muhammad Redzuan Othman. (1998). The Role of Makka-Educated Malays in the Development of Early Islamic Scholarship and Education in Malaya, Journal of Islamic Studies 9(2), 146-157.

Nik Azis Nik Pa (ed). (1999) Pendidikan Islam dan Pendidikan Bahasa Arab, Putrajaya: Yayasan Islam Hadhari.

Nik Aziz Nik Pa et al. (2008). Perjuangan Memperkasakan Pendidikan Di Malaysia. Kuala Lumpur: Utusan Publicationand Distributor Sdn. Bhd

Nur Hafizoh Idris\& Rohana Hamzah. (2013). Nilai Profesionalisme Bakal Guru Berteraskan Indikator Standard Guru Malaysia (SGM). Jurnal Teknologi, 60, 31-37.

Ramli Awang. (2012). Akidah dalam Kehidupan Muslim, Skudai: Universiti Teknologi Malaysia.

Syed Qutb. (1978). Ma'alim Fi al-Toriq, Jil Qurani Farid, Beirut: Dar al-Quran al-Karim.

Tajul Ariffin Nordin et al. (2002a). "Kurikulum Pendidikan Islam: Penjelasan Paradigma Pendidikan Bersepadu" (Kertas Kerja Wacana Pendidikan Islam Siri 1, 16 Julai 2002), Bangi: Fakulti Pendidikan, UKM.

Tajul Arifin et al. (2002b). Pendidikan Dan Pembangunan Manusia: Pendekatan Bersepadu, Selangor: As-Syabab Media, Selangor.

Tajul Arifin. (2005). Pendidikan Bersepadu Dalam Falsafah Pendidikan Negara. The paper was presented at Seminar Pendidikan 25 Tahun KUSZA, Kolej Agama Sultan Zainal Abidin, 19-20 November.

Wan Hassan Wan Embong. (2014). Keberkesanan Pengajaran Akidab Tingkatan 4, Universiti Malaya.

Zain Mohammad Syahatah et al. (1998). Turuq Tadris Mawad al-Ulum al-Syariyyah, Riyadh: WAMY. 